\title{
Scientific and Theoretical Foundations of the Formation of the Social Environment in the Family
}

\author{
Ulmasbek Umaralievich Karimov \\ Lecturer Fergana State University Fergana, Uzbekistan
}

\begin{abstract}
A
BSTRACT: The article discusses the scientific and theoretical foundations of the formation of the social environment in the family. It is known that our people have always supposed the family sacred and esteemed family relations. Therefore, the main link in any relationship related to the lifestyle of our people is the family and the social environment in the family. The formation of social relations in the family, the preservation and strengthening of the family, the creation of favorable conditions for the development of a healthy generation requires knowledge from people. Therefore, in studying and strengthening the family, it is necessary to pay special attention to the social relations in the family.
\end{abstract}

EY WORDS: Family, marriage, upbringing, modern family, national upbringing, family sociology, family psychology, healthy child, healthy family, social protection.

\section{NTRODUCTION}

Along with the classification of the family as a value and emphasizing its prestige in the life of society, an urgent task of great importance is to study the role of its strengthening guarantee factors, especially the upbringing of young people in a family. The family is a unique "state" within any state, a cell, a social "organization" that arises under certain conditions, in which the continuity of generations is ensured, our traditions, the sanctity of memory and, finally, ethnic culture are preserved, developed at the same time. The experience enriched by the next generation will be enriched with new traditions and passed on to future generations.

The development of society is achieved only through the improvement of children. Hence, the upbringing of harmoniously developed children has always been one of the urgent tasks of every age. As President Shavkat Mirziyoyev noted, "A child is a deposit in the hands of parents," say our great scholars. Today's life proves in every way that our children, their destiny and future are really very safe. If we do not bring up our children properly, if we do not pay attention to their behavior every day, every minute, if we do not teach them science, if we do not find a decent job, we will lose this deposit" [1]. This issue remains relevant. This issue remains relevant.

"A family is a group of people whose members are directly related to each other, and the older members of the group are responsible for caring for and helping the children"[2, 424]. In addition, "The family is the backbone of society, its first and foremost nucleus. Living as a conscious family belongs only to the human race among all creatures and creatures in the world" $[3,5]$. For centuries, people have associated their best dreams with a happy family. Because of the family, moral, legal, and social relationships are established between the couple, parents, and children. It is obvious that the family, by its very nature, reflects different aspects of society. That is why the family is the subject of a number of disciplines. These include ethnographic, demographic, psychology, pedagogy, medicine, law, economics, history, and family sociology. 
Oriental Journal of Social Sciences Vol.1 (1), pp.37-40, 22 May, 2021 Available online at http://www.supportscience.uz/index.php/ojss (C) 2021 Support Science LLC

DOI: https://doi.org/10.37547/supsci-ojss-01-06

\section{Methods}

It is known that from the beginning of the family to the present day, its types and socio-demographic structure have changed constantly. One of the important tasks of the social sciences is to study the changes in the types and structure of the family and the factors that affect them separately for each stage of development of society.

The family is an integral part of society. There is no nation, nation or society that has not taken into accounts the problems and values of the family and its surroundings in determining its history of development and prospects for development. Future can't be imagined without the interests of the family. After all, for everyone, family is the beginning of life, the prelude to all things. That is why the just policy pursued in our country, where human interests are recognized as the highest value, is aimed at strengthening this sacred corner in all respects. During the years of independence, the issues of social protection of the family, motherhood and childhood have been recognized as a priority of state policy in Uzbekistan.

"In today's form of family, family members are connected with each other by common life, economic, property, spiritual, legal, social relations, feelings of mutual responsibility. After all, every member of the family has a social place in the family" [4, 199]. Family issues serve through a number of disciplines and directly in establishing family resilience. Especially in the disciplines of family sociology and family psychology, the social functions of the family are studied in depth.

Family sociology conducts research and develops in an integral relationship with a number of social and natural sciences. These include psychology, demography, ethnography, history, social geography, political science, population sociology, birth sociology, death sociology, migration sociology, marriage sociology, mathematics, statistics, ecology. Family sociology also studies in detail the factors and characteristics of the performance of family tasks in different historical periods, social groups, peoples, states, and their relationship to family responsibilities. The most important task of the family is to create a new generation that ensures the birth of these children, that is, the continuity of society. Birth rates vary from nation to nation.

Marriage and family relations have been a part of the social institutions that make up the social system since ancient times, reflecting one aspect of the source of scientific research. It is known that each social institution is focused on performing a specific function. Sociologists in various fields have begun to study the specific functions of these social institutions and have tried to classify them.

The family represents a complex social reality in which various forms of social relations and processes are integrated. It is very difficult to compare any other structure with it, because in the family different human and social needs are met. The family represents such a social unit that it leaves an indelible mark on a person's entire life. It follows that it is not easy to engage in objective scientific research about the family. As one sociologist put it, "we know too much about the family in order to study it objectively". This means that it is not appropriate to do light research on the family.

\section{NALYSIS AND RESULTS}

The current state of development of society puts new social tasks in front of the family. The development of science and technology, industrial relations, the interaction of people, the range of relationships create emotional changes in the human psyche, and they also affect the nature of family life.

More complete and interesting information in this area can be obtained from the sources of sociology "Institutional School" by sociologists S. Lipset, D. Landberg and others. One of these social institutions is the family. According to the theories of classical sociologists, social institutions are divided into two: Simple and complex. In the classic example of a simple social institution, we can consider the institution of the family. "According to A. G. Kharchev, the family is a union of people by the nature of marriage, kinship, a link in the formation of social life and shared responsibilities" [5, 258]. In his time, M. Weber also spoke about social institutions and their functions. In his sociological theories, $\mathrm{O}$. Kont considers the family as the primary basis of society and interprets its origin as a natural state in human relations. "According to $\mathrm{O}$. Kont, all forms of social relations are reflected in the family, ie inequality (between generations and genders), dependence (between family members, head of the family, adults), etc." [5, 259].

The role of a healthy family in the development of any society is invaluable. Because just as the health of a living organism depends on the health of every cell that makes it up, so the family is the cell that makes up a whole organism called the state, society. A healthy child is the fruit of a strong and healthy family.

Indeed, the health of the lifestyle in the family serves to 
Oriental Journal of Social Sciences Vol.1 (1), pp.37-40, 22 May, 2021 Available online at http://www.supportscience.uz/index.php/ojss (C) 2021 Support Science LLC

DOI: https://doi.org/10.37547/supsci-ojss-01-06

further strengthen the social position of people in society. Because lifestyle is also inextricably linked with the spiritual world of people and plays an important role in their sense of thinking. Existing social conditions have a significant impact on people's lifestyles.

The family has two huge responsibilities: to give birth to children and to bring them up properly. Parents who have taken on a great goal are faced with tasks that cannot be forgotten. After all, a parent is also an educator in the family. Therefore, parents need to be vigilant and knowledgeable in providing the right education for their children.

The socio-psychological environment in the family, the necessary psychological calm, exemplary psychological attitude, mutual harmony have a positive impact on the formation of the child's personality.

In order to bring up the younger generation in a purposeful way, parents must have a comprehensive knowledge of the means and conditions of upbringing, taking into account the age and characteristics of children, their interests, abilities and abilities.

Interpersonal relationships in the family certainly affect the upbringing of a healthy mind. Because the level of parental attitude towards their children in many ways determines the level of children's attitude towards their parents

It is of great educational importance for parents to be loyal to each other in the eyes of children at all times in the process of interaction. From this, boys and girls take a role model. Loving fidelity between parents is an important psychological factor that strengthens the family, as well as giving it content and joy.

First and foremost, a parent who feels deeply responsible for the child's future and destiny should be a personal role model. After all, a child's behavior is judged by his or her parents based on their behavior. In the proper upbringing of a child in the family, the parents must work together to overcome difficulties. In this area, parental responsibilities cannot be divided into parts both father and mother is equally responsible. The nature of the family's influence on the spiritual world of children is determined by all aspects of family life.

\section{Conclusion}

One of the most important tasks today is to provide the most important knowledge on family issues and to prepare young people for family life in a healthy environment by forming appropriate skills and abilities based on them. As long as a healthy environment is formed in the family, a healthy child is born in such a family. A healthy social environment is created through the teachings of the ancestors, the example of the father, the love of the mother.

\section{EFERENCES}

1. Mirziyoev Sh.M. Let us be more united and work resolutely for the fate and future of our country./ Speech by President of the Republic of Uzbekistan Shavkat Mirziyoyev at the conference "Ensuring social stability, preserving the purity of our sacred religion - the need of the hour". // People's Word newspaper, June 16, 2017.

2. E.Giddens. Sociology. Study guide. Tashkent:, 2002.

3. The role of national and universal moral culture in family education / Najmidinova Karimakhon Usmonovna. - Tashkent: "Justice" 2016.

4. U. Karimov. Rules for the formation of family relationships and the moderation of the psychological climate in the family. Republican scientific-practical conference "Actual problems of psychological services in Uzbekistan". Tashkent:, 2015, October.

5. B.Aliev, G.Rafiqov, E. Muminov, B.Rakhmonov, T.Sultonov, N. Siddikov R.Mamatkulov, M.Mullajonova. Sociology. Study guide. Tashkent:, 2006.

6. A.I. Antonov, V.M. Medkov Sociology sem. Moscow: 1996.

7. General sociology(Edited by Alikoriev N. S. and Ubaydullaeva R.T.). Tashkent:, 1999.

8. Ganiev, B. (2015). Business-Ethics in Islam. Theoretical \& Applied Science, (7), 177-179.

9. Ganiyev, B. S. (2020). EDUCATION-PRIORITY SPHERE OF REFORM IN THE CONDITIONS OF A NEW StAGE OF DEVELOPMENT. Central Asian Problems of Modern Science and Education, 2020(1), 106-111.

10. Каримова, Г. Й. (2018). РОЛЬ КОНСТИТУЦИИ В ПОСТРОЕНИИ ПРАВОВОГО ГОСУДАРСТВА И ГРАЖДАНСКОГО ОБЩЕСТВА. Теория и практика современной науки, (2), 161-163.

11. Abdurakhmonova, M. M., ugli Mirzayev, M. A., Karimov, U. U., \& Karimova, G. Y. (2021). Information Culture And Ethical Education In The Globalization Century. The American Journal of Social Science and Education Innovations, 3(03), 384-388.

12. Каримов, У., \& Каримова, Г. (2018). ГЕОПОЛИТИЧЕСКАЯ КОНКУРЕНЦИЯ В ИНФОРМАЦИОННОМ ПРОСТРАНСТВЕ. In 
Oriental Journal of Social Sciences Vol.1 (1), pp.37-40, 22 May, 2021

Available online at http://www.supportscience.uz/index.php/ojss

(C) 2021 Support Science LLC

DOI: https://doi.org/10.37547/supsci-ojss-01-06

Перспективные информационные технологии (ПИТ 2018) (рp. 1368-1372).

13. Каримов, У. У. (2017). РОЛЬ СРЕДСТВ МАССОВОЙ ИНФОРМАЦИИ В ПРОЦЕССЕ ГЛОБАЛИЗАЦИИ. In Перспективные информационные технологии (ПИТ 2017) (рр. 1189-1192).

14. Normatova D. E. THE SOCIAL AND MORAL VIEWS OF MICHELLE ECKEM DE MONTEN //Scientific Bulletin of Namangan State University. - 2019. - T. 1. - №. 10. - C. 184-187.

15. Normatova, D. E. (2021). The Development Of Socio-Philosophical Thought In Western Europe On The Eve Of The End Of The Renaissance. The American Journal of Social Science and Education Innovations, 3(03), 371-377.

16. N.Usmonov. Sociology of the family. Methodical instructions. Fergana, 2012.

17. Хонкелдиева, К., \& Фарохиддинова, 3. (2020). Гендерное равенство как ценность права. Наука сегодня: фракты, тенденции, прогнозы [Текст]: материа, 61.

18. Odil Qoriev X. Constitution and civil society. Tashkent, 2002.

19. Yuldashev S. U. THE ROLE OF SOCIOCULTURAL TECHNOLOGIES IN SOCIETY //Scientific Bulletin of Namangan State University. - 2019. - T. 1. - №. 10. - C. 187-192.

20. Normatova, D. E. (2021). The Development Of Socio-Philosophical Thought In Western Europe On The Eve Of The End Of The Renaissance. The American Journal of Social Science and Education Innovations, 3(03), 371-377. 